\title{
Congenital cytomegalovirus infection presenting as cerebral palsy
}

Deepanjan Bhattacharya*, Inusha Panigrahi, Chakshu Chaudhry

Department of Paediatrics, Postgraduate Institute of Medical Education and Research, Chandigarh,India

*Corresponding Author: Deepanjan Bhattacharya, Professor, Department of Paediatrics, Postgraduate Institute of Medical Education and Research, Chandigarh, India.

Received date: January 15 2021; Accepted date: March 31, 2021; Published date: April 03,2021

Citation: D Bhattacharya, I Panigrahi, C Chaudhry. (2021) congenital cytomegalovirus infection presenting as cerebral palsy. International Journal of Clinical Case Reports and Reviews. 6(5); DOI: 10.31579/ 2690-4861/108

Copyright: (c) 2021, Inusha Panigrahi. This is an open access article distributed under the Creative Commons Attribution License, which permits unrestricted use, distribution, and reproduction in any medium, provided the original work is properly cited.

\begin{abstract}
A 9 month old boy presented with history of delayed attainment of milestones. He was born to a primigravida mother, with an uneventful perinatal period, but had a low birth weight $(2.1 \mathrm{~kg})$ for gestational age. There was no history of seizures, abnormal movements, loss of previously gained milestones or prior sibling deaths.

On examination, he had severe microcephaly, failure to thrive and hepatosplenomegaly. Neurological examination revealed severe axial hypotonia and spastic quadriplegia with brisk deep tendon reflexes and intermittent scissoring of lower limbs. Fundus examination and hearing evaluation were normal. His current developmental age was 4 months and developmental quotient was 30.
\end{abstract}

Keywords: congenital infection; cytomegalovirus; cerebral palsy

\section{Main Text}

A 9 month old boy presented with history of delayed attainment of milestones. He was born to a primigravida mother, with an uneventful perinatal period, but had a low birth weight $(2.1 \mathrm{~kg})$ for gestational age. There was no history of seizures, abnormal movements, loss of previously gained milestones or prior sibling deaths.

On examination, he had severe microcephaly, failure to thrive and hepatosplenomegaly. Neurological examination revealed severe axial hypotonia and spastic quadriplegia with brisk deep tendon reflexes and intermittent scissoring of lower limbs. Fundus examination and hearing evaluation were normal. His current developmental age was 4 months and developmental quotient was 30 .

Investigations revealed anemia, thrombocytopenia with elevated transaminase. Neuroimaging revealed hyperintensities in periventricular white matter on T2/FLAIR weighted images (Fig 1). Workup for toxoplasmosis and human immunodeficiency virus was negative. Realtime polymerase chain reaction using Cobas Taqman 48, showed a cytomegalovirus load of 35900 copies $/ \mathrm{ml}$.

A diagnosis of congenital CMV infection was made and he was started on oral valganciclovir. 


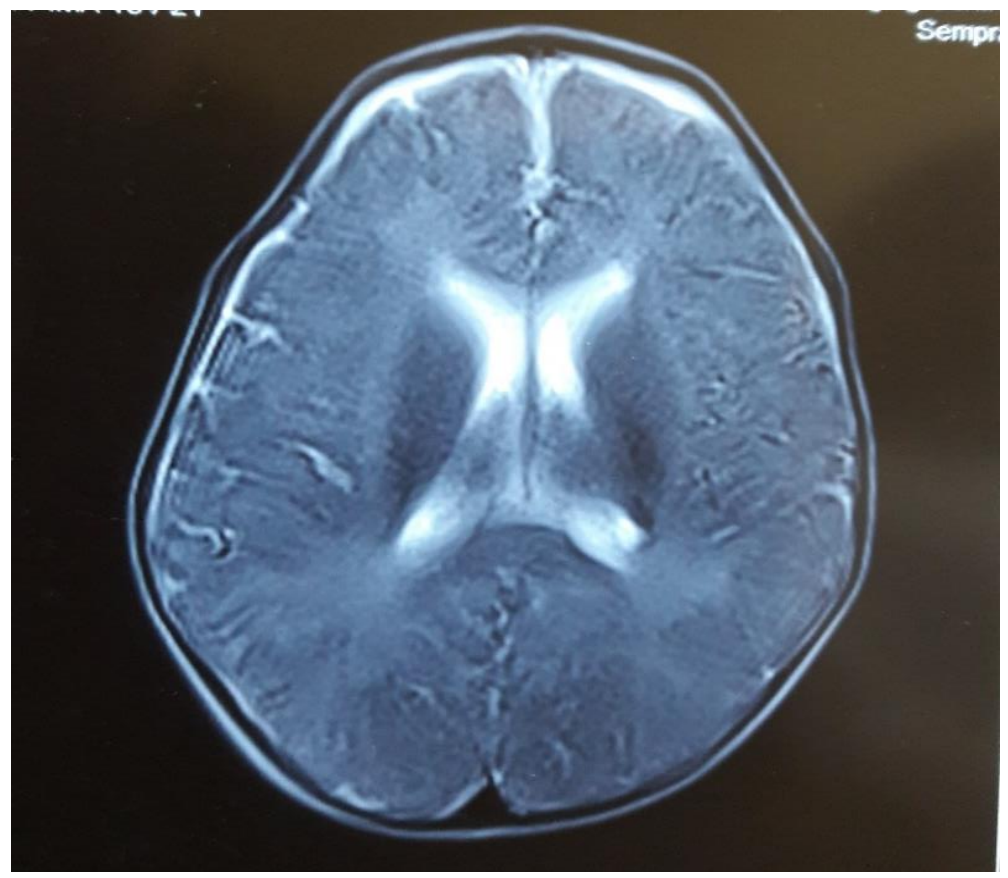

Figure 1: T2 weighted axial images on MRI showing hyperintensities in periventricular white matter

Congenital cytomegalovirus infection is the commonest intrauterine infection, with a global prevalence rate of $0.2-2.2 \%$. Transmission is usually secondary to maternal viremia, which may be asymptomatic.

The diagnosis is often missed in clinical practice, due to lack of physician awareness and its myriad ways of presentation. Only $10 \%$ of congenital CMV infection is symptomatic, masking its true prevalence. Subtle clues like hepatosplenomegaly and cytopenia can help in suspecting diagnosis [3].

\section{References}

1. Malm G, Engman ML. (2007) Congenital cytomegalovirus infections. Semin. Fetal Neonatal Med. 12(3):154-159

2. Kenneson A, Cannon MJ. (2007) Review and meta-analysis of the epidemiology of congenital cytomegalovirus (CMV) infection. Rev Med Virol 17(4): 253-76

3. Smithers-Sheedy H, Raynes-Greenow C, Badawi N, Fernandez MA, Kesson A,McIntyre S, Leung KC, et al. (2017) Congenital Cytomegalovirus among Children with Cerebral Palsy. J Pediatr. Feb;181:267-271.

This work is licensed under Creative Commons Attribution 4.0 License

\section{To Submit Your Article Click Here: Submit Manuscript}

Ready to submit your research? Choose Auctores and benefit from:

* fast, convenient online submission

* rigorous peer review by experienced research in your field

* rapid publication on acceptance

* authors retain copyrights

* unique DOI for all articles

* immediate, unrestricted online access

At Auctores, research is always in progress.

Learn more www.auctoresonline.org/journals/international-journal-ofclinical-case-reports-and-reviews 